\title{
Effect of diphenylhydantoin on the reproductive function of the male rat
}

\author{
D A N F. COHN, T.A X ELRO D, Z . T. HOMON NAI, G. PAZ, \\ M. STR E I F LER, A N D P. F. K R A I C E R \\ From the Department of Neurology, Ichilov Hospital and Medical Center, Soferman Institute for \\ Study of Fertility, Maternity Hospital, Hakirya, and Sackler School of Medicine, Tel-Aviv University, \\ Tel-Aviv, Israel
}

SUMMARY Male rats were injected with 5,10 , and $20 \mathrm{mg}$ diphenylhydantoin daily for two months and then caged for five days with cyclic females. Thereafter the males underwent necropsy, the organs of the genital tract were examined, and found to be unaffected. Blood testosterone and Leydig cell counts were normal. A significant reduction of fertility was observed which appears to be loss of libido on behavioural grounds. Except for similar behavioural changes described in human epileptics no further reports are available concerning anticonvulsants and fertility. Our findings indicate that there is no reason to suspect that diphenylhydantoin has endocrine-mediated effects on male fertility in the rat.

In choosing drugs for long-term therapy of young people, the possible effects on fertility must be considered. The treatment of epilepsy in people of reproductive age is a typical example since medication must be continued for very long periods. The possible immediate or delayed effects of anticonvulsant drugs on reproduction have not been studied adequately. From a recent preliminary report (Christiansen and Lund, 1976) it seems that there is indeed cause for concern. Young male epileptics showed endocrine and behavioural abnormalities. The establishment of an antifertility effect of an anticonvulsant drug would be of double significance. In addition to the obvious clinical implications, it might offer means for the experimental manipulation of male fecundity in animal models. For this reason we undertook to examine the long-term effects of a commonly prescribed antiepileptic drug, diphenylhydantoin (DPH), on the reproductive function of male rats.

\section{Material and methods}

The rats used in this study were male albinos from the breeding colony of the Faculty of Life

Address for reprint requests: Dr Dan F. Cohn, Department of Neurology, Ichilov Hospital and Medical Center, Weizman Ave, Tel-Aviv, Israel.

Accepted 30 March 1978
Sciences of this university. They were fed pelleted animal food (Ambar, Hadera-Israel) and tap water ad lib. The animals were injected subcutaneously every day with either $0.1,0.2$, or $0.4 \mathrm{ml}$ per animal of a solution containing $50 \mathrm{mg} \mathrm{DPH} / \mathrm{ml}$ (Dilantin, Parke, Davis and Company, USA). At the end of two months of treatment, the fertility of the males was tested by caging them with two cyclic females for five days. The males were considered fertile if at least one of the females became pregnant. The males underwent necropsy after decapitation. Blood was collected and serum prepared. The organs of the male genital tract were dissected and weighed. The epididymis was trimmed carefully, and minced in Toyoda and Chang (1974) medium. The tissue debris was removed from the sperm suspension by filtration through a fine stainless steel screen. Sperm concentration was determined haemocytometrically. The total number of epididymal sperm per male was calculated. Serum testosterone concentration was estimated by radioimmunoassay (RIA) using rabbit antitestosterone serum (MilesYeda Ltd, Israel).

Four rats received $0.4 \mathrm{ml}$ daily of DPH for 12 days. Prostate, coagulating gland, epididymis, and testis were homogenised, each in $1 \mathrm{ml}$ of distilled water. The supernatants and serum were taken for estimation of DPH using a commercial RIA kit (Radiochemical Centre UK, Kit IM 90). 
Seven proestrous female rats were mated with DPH-treated males, $0.4 \mathrm{ml} /$ daily for seven days. The post-coital uterine fluid was collected for DPH estimation.

\section{Results}

The doses of DPH chosen in this study were approximately 20,40 , and $80 \mathrm{mg} / \mathrm{kg}$ body weight. These doses, which were similar to, or greater than those used in humans, had no discernible effect on the organs of the genital tract (Table 1) or on other indirect parameters of fertility (Table 2). Nevertheless, at a dose of $20 \mathrm{mg}$ per rat a significant reduction in fertility was observed $(P=0.045$ by Fisher's Exact Probability Test). Observation of these males while they cohabited with proestrous females suggested a low libido. The treated males seemed less excited and made fewer attempts to mount the females. This apparent decrease in libido was not due to androgen deficiency. Both blood testosterone and Leydig cell counts were normal. The DPH concentration in the serum of four treated animals was 10.9$1.9 \mu \mathrm{g} / \mathrm{g}$ (mean SEM). In their testes it was 1.9$0.2 \mu \mathrm{g} / \mathrm{g}$, and in pooled tissues of epididymis 2.15 , coagulating glands 3.1 , and prostate $2.34 \mu \mathrm{g} / \mathrm{g}$. In post-coital uterine fluid DPH levels were undetectably low.

\section{Discussion}

Our results indicate that DPH has no deleterious effect on the male reproductive tract, although a reduction in fertility rate may follow excessive doses. At a dose level believed to resemble most closely that used in human epilepsy-namely, $5 \mathrm{mg}$ daily per rat, being approximately $20 \mathrm{mg} / \mathrm{kg}$ - fertility was unaffected. This dose is several times higher than the average clinical dose, but in view of the rat's high rate of metabolic turnover, these doses were not unreasonable. In fact, the mean rat plasma level seen after injection of $0.4 \mathrm{ml}$ daily was $11 \mu \mathrm{g} / \mathrm{ml}$ which is consistent with the expected therapeutic blood level in DPHtreated human epileptics. Higher doses were not tested, since already at the levels employed there were extensive cutaneous necrosis at the injection sites.

The test period of 70 days was adequate since it is approximately the same as the total time of sperm production in the rat. Nevertheless, in view of the duration of chronic DPH treatment in human epilepsy, this might be considered a relatively short treatment course. The major effect of DPH on male fertility appeared to be behavioural, namely loss of libido. It is interesting that Christiansen and Lund (1976) report similar behavioural changes in treated epileptics. In view

Table 1 Effect of diphenylhydantoin 5, 10, or $20 \mathrm{mg}$ given daily for 10 weeks on the reproductive organs of the rat. The rats weighed $289 \pm 9.4 \mathrm{~g}$. Numbers are means $\pm S E M$

\begin{tabular}{|c|c|c|c|c|}
\hline \multirow[t]{2}{*}{ Organ weight } & \multirow[t]{2}{*}{ Control } & \multicolumn{3}{|c|}{ Dosage of diphenylhydantoin (mg/day) } \\
\hline & & 5 & 10 & 20 \\
\hline Number in group & 5 & 7 & 5 & 5 \\
\hline $\begin{array}{l}\text { Testis }(\mathrm{g} / 100 \mathrm{~g} \text { bodyweight) } \\
\text { Epididymis (mg/100 } \mathrm{g} \text { bodyweight) } \\
\text { Prostate }(\mathrm{mg} / 100 \mathrm{~g} \text { bodyweight) } \\
\text { Seminal vesicle (mg/100 } \mathrm{g} \text { bodyweight) } \\
\text { Coagulating gland (mg/100 } \mathrm{g} \text { bodyweight) }\end{array}$ & $\begin{array}{l}1.09 \pm 0.03 \\
336 \pm 11 \\
211 \pm 22 \\
339 \pm 48 \\
72 \pm 8\end{array}$ & $\begin{array}{l}0.95 \pm 0.05 \\
339 \pm 17 \\
246 \pm 23 \\
420 \pm 19 \\
89 \pm 6\end{array}$ & $\begin{array}{l}0.93 \pm 0.04 \\
319 \pm 88 \\
295 \pm 21 \\
466 \pm 24 \\
82 \pm 6\end{array}$ & $\begin{array}{l}1.11 \pm 0.04 \\
343 \pm 67 \\
231 \pm 18 \\
356 \pm 38 \\
68 \pm 8\end{array}$ \\
\hline
\end{tabular}

Table 2 Effect of daily administration of diphenylhydantoin on rat fertility. Numbers are means $\pm S E M$

\begin{tabular}{|c|c|c|c|c|}
\hline \multirow[t]{2}{*}{ Fertility effect } & \multirow[t]{2}{*}{ Control } & \multicolumn{3}{|c|}{ Dosage of diphenylhydantoin (mg/day) } \\
\hline & & 5 & 10 & 20 \\
\hline Number in group & 5 & 7 & 5 & 5 \\
\hline $\begin{array}{l}\text { Fertility rate (number of females pregnant/total) } \\
\text { Epididymal content of sperm (millions) } \\
\text { Motile sperm (\%) } \\
\text { Serum testosterone (ng/ml) } \\
\text { Leydig cells (millions/animal) }\end{array}$ & $\begin{array}{l}7 / 7 \\
144 \pm 34 \\
72 \pm 5 \\
2.4 \pm 0.34 \\
34 \pm 6.8\end{array}$ & $\begin{array}{l}7 / 7 \\
123 \pm 5 \\
80 \pm 2 \\
4.31 \pm 0.64 \\
-\end{array}$ & $\begin{array}{l}4 / 5 \\
201 \pm 21 \\
83 \pm 4 \\
2.4 \pm 0.80 \\
39 \pm 5.6\end{array}$ & $\begin{array}{l}2 / 5^{*} \\
182 \pm 19 \\
74 \pm 4 \\
2.8 \pm 0.75 \\
34 \pm 3.5\end{array}$ \\
\hline
\end{tabular}

*Significantly lower than control, $\mathrm{P}=\mathbf{0 . 0 4 5}$. 
of our findings, there is no reason to suspect that DPH has endocrine-mediated effects on male fertility. The behavioural effects, in our view, merit further investigation.

\section{References}

Christiansen, P., and Lund, M. (1976). Sexual potency, testicular function and excretion of sexual hor- mones in male epileptics. In Proceedings of the Seventh International Symposium on Epilepsey, pp. 190-191. Edited by D. Janz. Georg Thieme Verlag: Stuttgart.

Toyoda, Y., and Chang, M. C. (1974). Fertilization of rat eggs in vitro by epididymal spermatozoa and development of eggs following transfer. Journal of Reproduction and Fertility, 36, 9-22. 